\title{
THE IMPORTANCE AND ROLE OF VIRTUES IN THE SPIRITUAL DEVELOPMENT OF A PERSON
}

\author{
Ph.D. Candidate Constantin Valentin BUGIULESCU, \\ Faculty of Orthodox Theology, \\ "Justinian Patriarch", University of Bucharest, \\ ROMANIA, \\ E-mail: bugiulescu_constantin@yahoo.com
}

\begin{abstract}
Virtues are the first to contribute to the deeper definition of the soul that is why the acquisition of virtues is a continuous and steady training to imitate the life of obedience and the sacrifice of Christ's love for its fellowmen. Acquiring virtues is a precondition for man to open up his ability to love. All virtues lead the mind to the pursuit of divine love, which is, in fact, an embodiment of the divinity that is secretly lowered into the nature of man. It is the virtue that gives man the constant disposition to do the good. This virtuous disposition of man is mysteriously hidden by God in the depth of the soul. It is revealed through body in the process of doing. If the soul lacked the flesh, it would only have a virtuous mood or enjoy the virtues of virtue itself. That is why, it is by the flesh that the manifestation of these goods of virtues towards all the others is done. From this point of view, the social character of virtues is observed.
\end{abstract}

Keywords: virtues; spiritual life; moral life; Christianity;

\section{INTRODUCTION}

Virtues are the means of connecting and communication between man and God. They are a rational skill of the man who perseveres in freeing from the bondage of passions and imprinting, by imitation, the divine attributes in his nature. "Virtue means the rule of mind by mind, the mind being the one who wants all that God desires from the human nature; guided, taught and guided by reason, the mind desires all that God desires in regard to the human nature, "says St. Maximus ${ }^{1}$. In this sense, virtue is the one that appears to be the "last desired good " by man, for through virtue that total imprint of divine goodness in man is accomplished, the one which St. Maximus calls "perihoretic action."

Only in God, by virtue, is everything known by its being, but in connection with God. In God (in virtue) we will find out what, how and to what purpose are they. By virtue of "we will not direct our desire to know towards something determined, the knowledge of

\footnotetext{
${ }^{1}$ In the thought of St. Maximus, virtue is a rational skill because reason, as the power of mind of analytical and distinctive knowledge, is that which constrains and submits the idleness and lust to the mind, as powers that bind the soul either to the body or to the plan above nature that opens to your mind. It is the mind that stands above these three powers of mind (reason, indolence, and lust) analytically analyzing both the totals of the nature and those that are above the wings. Virtue is a rational understanding because it is the reason that cleanses sinful thoughts, both indolence and lust (as spiritual powers), thereby succeeding in gaining from them an undivided will between good and evil, thus lifting man to knowledge full of pure feeling. See St. Maximus, Ambigua, PG. 91, col. 1068C; Romanian translation, PSB 80, p. 68;
} 
any thing or the one directed at anything after God being overtaken by us," says Saint Maximus .

Virtue is from God and toward God. St. Maximus sees it as being:

"the movement of the will in resonance to the reason we were created from, pre-existing in God, which is in God and within God, and if its movement is in accordance with reason, man will fully reach into God, becoming through full growth more and more in God, or even God by grace". 3

Following Dionysius the Pseudo-Areopagite, Saint Maximus states that rationales are "divine willingness," but they are not inertial models, but are God's creative powers that call created rational beings to contemplate the patterns of things, and "one who has been taught to look godly to the rationale of things can easily develop and differently the meaning of these ideas". Thus, any reason of any existing created thing is, in some way, the being of virtue, and because reason is the expression of the God's will, that is, what God wished and still wishes for created rational beings to make, we can powerfully state that the virtue of all virtues is our Lord Jesus Christ Himself, the Reason or the Incarnated Word. That is why St. Maximus states: "Everyone who shares virtue with an unshakable manner undoubtedly partakes himself of God, the being of virtues" ${ }^{4}$.

Virtues are naturally natural, they exist in all men the same way, the inequality between us consisting in the fact that we do not all put the same thing into the work of the flesh. In this sense Saint Maximus says: "The purpose for which we were created is to put into the work all the same things of nature, so that it should look like a nature in all, so a virtue, not receiving in it more for some or less in others, and the endeavour and the struggle that follows have been added to the virtue lovers only for the purpose of removing the deceit that is being introduced into the soul by the senses and not to introduce virtues like something new from the outside". So, virtues are in us since our creation. That is why, says Saint Maximus, "as soon as the deception is fully removed, the soul shows the brightness of virtue. ${ }^{5}$

\section{VIRTUE AND SPIRITUAL PROGRESS OF MAN}

The spiritual progress of man takes place in two stages: the practical stage and the contemplative stage. Those who are in the first stage have not yet gained steadfastness in the realization of the good because they have failed to totally remove himself from the world, from the bodily affection. That is why, for those in the practical phase, a determination in the realization of virtues is required, because the virtues are those that break the chains of the bodily affection, realizing the total estrangement from those belonging the being and those from the outside, while being familiar with contemplation and with God, says St. Maximus. ${ }^{6}$ By means of virtues one can accede to the stage of contemplation, in which those who are in

\footnotetext{
${ }^{2}$ St. Maximus says that the natural tendency of the will created for Good is present in man, because there is a supreme all-powerful Good, therefore the will tends naturally for the good, and once in God, as Allencompassing Good, it can no longer depart from Him . See St. Maximus, PG. 91, col. 1077B; English translation from Romanian., p. 79;

${ }^{3}$ Ibid, PG. 91, col. 1080C; English from Rom., p. 81;

${ }^{44}$ Ibid, PG. 91, col. 1081D-1084A; English from Rom., p. 85

${ }^{5}$ Idem, The dispute of Saint Maximus with Pyrhus, PG. 91 col. 309C, Rom. translation by Father. Dumitru Stăniloae, in P.S.B. 81, Ed. I.B.M. al B.O.R., 1990, p 333

${ }^{6}$ Idem, Ambigua, PG. 91, col. 1109AB; .rom. translation, PSB 80, pp. 108-109
} 
this phase are resolute, are totally immersed in knowledge, through perseverance and steadfastness in virtue.

By virtue of virtue it is necessary to overcome this body which is under the control of affection towards passions. Through the two stages, practical and contemplative, virtues work by overcoming the body possessed by passions (subject to degradation). St. Maximus says that it is not the body, in general, that must be overcome, but the passionate state of the body, enshrined in the flesh by means of passions.

The manifestation of virtues in the flesh removes this sinful state, the purification and elevation of its model, God, its Creator being performed. Besides, this is also a desire of the body that it is longing for. St. Maximus says that the virtue of the body makes the body "beautified with divine appearances". ${ }^{7}$ Just as the soul takes "earthly face" through the body, so does the body takes "the divine image" through the intercession of virtues within it. Through the intercession of virtues in the flesh, the imprinting of divine spirituality in the flesh is accomplished. A convincing example of this is the Holy Revels of the Saints, who, being filled in the flesh, by printing, by the intercession of virtues, by divine grace, become whole, sacred and carriers of the "spirit".

St. Maximus says that divine life is an icon of virtues laid for everyone's sight, for imitation purpose, through the body, "the body is the above-virtuous mother of virtues." Virtue is the harmonization of the soul as an opening to love made through the body. When virtue is related to love, it creates true communion, and when it is related to passions, this communion is destroyed. ${ }^{9}$ Virtues are the ones that make man permanent with God, so much so that he becomes "god," after receiving the grace within. For this we must understand virtue as the continuous movement of nature toward God. Virtue requires a continuous effort, for "the only way to end the virtue is the fall," Saint Maximus states. Virtue is the one that never dies, because it is understood as a continuous state of fulfilment of good. Therefore, understood as a state, virtue can never stop, but understood as a way of being, virtue decreases or becomes inactive. ${ }^{10}$

St. Maximus states: "Stopping on the way of acquiring virtues is the beginning of sin", so any hesitation in getting the virtuous state is dangerous, even if this stop does not mean falling into sin. Stopping on the way of gaining virtue is temptation, the moment when reason still fulfils its role of showing the false character of the deed, but an extension of this interruption will surely lead to the fall of sin.

In the sinful state, virtue remains at the state of remembrance, and may encompass potentiating forms with the help of reason, which in sin always has the form of consciousness; the latter cannot be conceived as a blind movement, but as a moral power, a form of rebellion of the our nature against the irrationality and the falsehood created by sin. This form of revolt of reason is moved by the Holy Spirit, but also by the Holy Angels, St. Maximus states ${ }^{11}$.

\footnotetext{
${ }^{7}$ Ibid, PG. 91, col. 1112A; Romanian translation, p 110;

${ }^{8}$ Idem, Quaestiones ad Thalassium, PG, 90, col. 244BC; Romanian translation., Father. Prof. Dumitru Stăniloae in Romanian Philokalia, vol. III, electronic edition, Apologeticum Publishing House, (www. angelfire.com/space2/carti/), 2009, p. 22

${ }^{9}$ See Aristotel Papanikolaou, Learning How to Love: Saint Maximus on Virtue, in Knowing the Purpose of Creation Through the Resurrection-Proceeding of the Symposium on St. Maximus the Confessor, Sebastian Press \& The Faculty of Orthodox Theology- University of Belgrade, 2013, p.241

${ }^{10}$ Virtue is a state of human being, not a state of its own, but a mood for the realization of the good.

${ }^{11}$ Of Saint Maximus, PG 90, col. 305ABC; rom. translation, p. 81
} 
Therefore, only virtuous life is the only life according to the reason of nature, virtue being the active mode of the being of man, while sin is the passive mode of being. But according to the active or passive work of man, the work of virtues is mysterious, and it is only performed in grace by the Holy Spirit.

\section{VIRTUES - MEANS OF KNOWING AND UNION OF MAN WITH GOD}

Virtue is the development of man according to God, with absolute good through self. This human development is accomplished, as we can see, through skill. It is considered to be a good practice for us who cannot have good by being, and this good development of man through virtue means, in fact, participation to God's life, to the good life. The willingness to contribute to our perfection is expressed by virtue, which is the expression of our liberty, as the gift of God. Virtue is the one that highlights the good that exists in us since creation, as a cause and purpose at the same time.

St. Maximus says, "By pushing the way of good by virtue we become gods, receiving the power of being gods from God, as some who have freely added, by our own choice, the resemblance, made by virtue, to the natural good of the form". By doing so, Saint Maxim wants to show that the good we have received along with the creation is developed by us by means of virtues. The performing of good by means of virtue equals the development according to the nature and the reason planted in nature by the Creator, which will bring, through progress according to nature, the deification of the human nature by grace. Thus, by means of virtue a progress is being aimed at, a development of nature to its deification in accordance to nature. In this regard, Saint Maximus states: "God descends by grace to man, because man is raised up in grace of God by means of virtues," for "it is with and through Him that we are alive, we move and we are" (Acts 17:28).

Man, as a "theological" being, rational, free, spirited, has the tension of uniting with God planted in his being, by reason; this unconditionally draws him and takes the whole weight of sin off, making him truly free and rational, worthy of union with Him, living by virtue, the fullness of existence, in the light of which he truly knows himself. By knowing himself, he recognizes the infinite beauty of the Archetype, forgotten because of the sin; because man is from God "as God", in and through God. This union is accomplished in grace through the work of the Holy Spirit, a work that exceeds both our powers and the world we live in, assisted by the power of virtues planted in the human being.

In this process all virtues contribute to the formation of an inseparable organism, worthy of union with God. St Justin Popovich states:

"All virtues are in themselves a spiritual chain that connects man to God, each virtue increasing its power with another virtue to becoming the same being, the differences between them being the honour granted to each one" ${ }^{\text {12. }}$.

In this regard, the relationship between the theological virtues, faith, hope and love, with the other virtues, must be understood.

Considered to be divine goods flowing directly from God over our nature and being in direct connection with God, virtues help us to come closer to God and to get intimate to Him, because of the grace that is poured upon us through them. Faith, hope and love, as theological virtues ("divine virtues"), are the complete, perfect means of knowing and uniting man with God. That is why Saint Maxim states:

\footnotetext{
${ }^{12}$ Saint Justin Popovich, The Path to Knowing God,. rom. transl. by Monahia Domnica (Țalea), Egumenița Publishing House, Galați, 2014, p. 117;
} 
"Knowledge and union are gained in the paths of love so that we can always be in and with God. In this union the intellect receives intelligible enlightenment, in this light man knows God. Then, as far as possible for the human spirit, we fully enter into the nature of God's attributes through the Holy Spirit". 13

We could say that these three virtues, called theological virtues, are the ones that bring us into the divine universe, to God, because through them God infiltrates ineffably in the mind and heart of man.

Virtue unfolds on two levels: sensitive and intelligible. The virtue of the body has as its tendency the end or the victory over the passions that bring the unmixed good to the being, and the virtue of the soul is aimed at the end or the removal of any ignorance enveloping the mind and reason, thus bringing simple truth to the being, according to Saint Maxim. Un combined good and simple truth are the effects of the theological virtues or, more precisely, the purpose of these virtues, since faith is the firmness of nature into the truth and the good, hope is the promise of nature in the acquisition of the truth and the good, and love is the desire for unity, in truth and in goodness, with God, as the last desired good.

We could say that these three virtues, called theological virtues, are the ones that bring us into the divine universe, to God, because through them God infiltrates ineffably in the mind and heart of man.Virtue unfolds on two levels: sensible and intelligible. The virtue of the body has as its tendency the end or the victory over the passions that bring to the being the unmixed good, and the virtue of the soul is aimed at the end or the removal of any ignorance enveloping the mind and reason, thus bringing simple truth to the being, says Saint Maxim. Un-blamed good and simple truth are the effects of the theological virtues or, more precisely, the purpose of these virtues, since faith is the non-clinging of the flesh in truth and good, hope is the promise of the flesh in the acquisition of truth and good, and love is the desire for unity, in truth and in goodness, with God, as the last desired good. Knowledge and union of man with God are the effects of these three virtues, which at the same time, stands for a crowning of all virtues. "Love is the virtue of all virtues, all virtues assist the mind in the pursuit of divine love." ${ }^{14}$. The theological virtues are the only virtues that, by their substance, materialize all other virtues. In this regard, Saint Maximus states:

\footnotetext{
"He who loves God surely loves his neighbour, for the fruits of love are: doing good to the neighbour from the bottom of your heart, to endure for a long time, to be tolerant, and to use things for the right reason".
}

Love is the essence and connection of the person. By love, the human person frees himself from the impersonal nothingness and draws near the personal God. "Perfect becomes the being of person whose love never ceases," says St. Justin Popovich. ${ }^{16}$ The power of love shared with the soul of the Holy Spirit, though distinct from the divine hypostasis of the Spirit, is not a created effect, a mere coincidence whose existence would hinge upon our created nature, but an uncreated grant, divine and deifying energy in which we partake in God in a realistic manner. Love is from God, says St. John the Evangelist (1 John 4: 7). But this love as a divine gift presupposes a personal disposition of human nature, a seed or power of love in the human being called to attain perfection in love.

\footnotetext{
${ }^{13}$ Maxime le Confesseur, Centuries sur la Charité, II, 26. trad. Pegon, Sources chrétiennes 9, p.101, apud Vladimir Lossky, Vision of God, translated by Prof. dr. Remus Rus, EIBMBOR, Bucharest, 1995, p. 111

${ }^{14}$ Aristotel Papanikolaou, op.cit., p. 241;

${ }^{15}$ Saint Maximus the Confessor, Heads of Love, rom. translation by Rev. prof. Dumitru Stăniloae, Humanitas, Bucharest, 2009, pp. 53-54;

${ }^{16}$ Saint Justin Popovich, op.cit., p. 127;
} 


\section{VIRTUE OF LOVE AND DEIFICATION OF MAN}

The purpose of a Christian is to unite with God through and in love. In order to achieve perfection, the experience of God must first be purified. Ascetism, performed through love, purifies reason, and descends into the heart, the mystic of the intellect unites by love with the mystic of the heart, the union of these two opening the way to a type of spiritualization that will engage the whole being of man.

Perfection involves the whole human being; while man remains human with his soul and body by nature, he becomes with his soul and body entirely god out of grace, Saint Maxim the Confessor states. ${ }^{17}$ Deification determines everything; it is the supreme target of human will. This causes man to feel urged to come to unity with God, to overcome the limited nature in its pursuit. ${ }^{18}$ Perfection stands for a mystical experience of the eternal presence of God within man, and this is accomplished beyond intellect and senses, by overcoming them; that is why it is addressed to man as a whole. Man's perfection is the result of an infinite process of reason that loves the Good. Only the love of good lives forever; only this love is true knowledge.

Deification is the fruit of perfect love, a mind cleansed of passion and affection for everything in the world. Impassion is the most active opening of the soul toward God and toward others; it is love as the culminating virtue or is the unity of the soul with the body and man as a whole with the universe as a whole. Love is in all; it is the tool for deification by excellence, salvation being gained by the love for God and by deeds: "Through one's patience one will acquire his soul" (Luke 21:19). St. Maximus says, "God draws to Him the mind purified through love, as the sun draws the healthy eye to light" ${ }^{19}$, and once the mind is united to God, it bears in itself almost all the divine qualities.

In God, man and the world do not become two distinct realities, but they are enlightened, transfigured, they become a true being, freeing themselves from non-being. The peak of spiritual life, as Nicolai Berdyaev states, is not only the union with God, but the realization of its love and creative force through this union directed towards any creature: "Love is truly the creation. Through this love the commandment of Christ is fulfilled: love for God, love for man. "20. "Happy is the man who can love every being with the same love," St. Maximus says. It is the love that crowns the being and spiritualizes the soul. It is the mystical love or the mystic (mystery) of the love of the new birth, of the spiritual birth. In other words, it is the fulfilment of the commandment of Christ: "Thou shalt love the Lord thy God, and thy neighbour as thyself" (Mark 12: 30) ${ }^{21}$, or "love more, learning at the same time how to love."

In love, God and man become models for each other: God is the model by which man has become saint, and the holy man is the pattern God has become man, ${ }^{22}$ St. Maximus says. Out of love, God's greatest nearness to the world has come about, which has produced His relation to man, and man's love produces deification as the closest approach to God. God equals man through love, and man rises to God through love. The mind that rises to God

\footnotetext{
${ }^{17}$ See Maximus the Confessor, Ambigua, PG. 91, col. 1344D; Rom. transl., PSB 80, p. 291;

${ }^{18}$ Deification is the participation in the life of God; the deified man, however, does not become God by nature, but he remains human, just as reddened iron does not become fire but remains iron. Christ being God, communion with Him is communion with God, that is, deification through grace.

${ }^{19}$ Idem, Capita de charitate, PG. 90, col. 967A; rom. transl., p. 54

${ }^{20}$ Nicolai Berdyaev, Spirit and freedom. A test of Christian philosophy, transl. by Stelian Lăcătușu, Paideia, Bucharest, 2009, p. 283;

${ }^{21}$ Aristotel Papanikolaou, op.cit., p. 241;

${ }^{22}$ Saint Maximus the Confessor, Ambigua, PG. 91, 1113B; Rom. transl., PSB 80, p. 112;
} 
through love becomes at that moment divine; love makes us become "god" as the effect of the presence of Christ descended to us out of love for us people. ${ }^{23}$

The whole spiritual progress of man is realized through and in love, the ascetic mood cannot lead anywhere without love. Therefore, to the extent that reason is maintained in the constant love of God, the power of knowledge grows and love grows, and becomes stronger. Perfection consists in this stability and the consolidation of reason in the love of God.

The virtue of love, as a theological virtue, ultimately, immediately and directly aims to the union of man with God, the source of love. Love is the appearance of God in the soul of man, such as faith is the revelation of man before God, St. Justin Popovich notices. ${ }^{24}$ To gain this virtue, man needs divine grace, as a worker of love within man. Love cannot be attained very easily or in an automatic way; the latter is acquired with much effort, patience, vigilance and struggle. That is why the one who has love will never fall, because he is in a constant struggle for this love. Man cannot attain love alone by himself but by participating in this process with his own will, by freely receiving the loving power that is accomplished in the mutual dialogue, by grace, with God. With the help of grace, love becomes a powerful completion by which God freely leads man on the path of perfection to Him. Thus, love becomes the architect of our being, who secretly builds into it all other virtues.

It is love that perfects the human nature until it "makes it appear in unity and identity with the divine nature through grace.", In the love of God, every human person finds perfection; or in other words, people cannot reach their perfection unless the unity of human nature is achieved. The love of God will therefore necessarily be related to the love of the neighbour. This perfect love will make man look like Christ, for he will be united by his nature created with all mankind, and he will reunite in his person what is created with what is uncreated, the human compound and the grace of God. Thus in love for one's neighbour will be the sign of the true love for God. St. Maximus says that the love of God and the love for the neighbour are the two dinars that the Saviour gave to the caretaker of the guest house to care for you. The virtue of love is the safest "way" to God, and "the one who has acquired the virtue of love has acquired God Himself, because God is love" (1 John 4:16), St. Maximus states. ${ }^{26}$

So all the conditions necessary for the attainment of the last purpose, deification, are offered by God in grace through the work of virtues. But union with God is not the fruit of an organic and unconscious process; it is fulfilled in us, in love by the grace of the Holy Spirit and our freedom.

\section{CONCLUSION}

Every man is part of God, on the one hand, considering the pre-existing in God reason that he was created from; on the other hand, because if he moves according to this reason he will fully reach God. That is why reason has always the tendency to keep nature in the rationality that characterizes it, helping the nature in the practice of removing passions through virtues. By reason, man is called to the right judgment; he is called to the relationship of love that is realized in the rational and conscious union with God. This relationship of love, which is mutual, is the shortest way to God. Through the way of virtue,

\footnotetext{
${ }^{23}$ Basile Tatakis, Byzantine philosophy, Romanian translation by Eduard Florin Tudor, Second Edition, Nemira, Bucharest, 2013, p. 123.

${ }^{24}$ Saint Justin Popovich, p. 131.

${ }^{25}$ Saint Maximus the Confessor, PG. 91, col.1402; rom. translation, p. 342.

${ }^{26}$ Idem, Capita de charitate, PG. 90, col. 1065CD and 1073A; rom. Translation, pp. 109, 113.
} 
a stability of reason is achieved in the completion of the good, as an expression of soul experience and self-control. By means of virtue the soul strengthens and stabilizes itself, acquiring a firmer character in the choice of the good, and this stability is supported by reason. In this respect, Saint Maximus says: "Virtue is the way of maintaining and actively achieving the reason of nature." 27

So, through virtue, the power of the Divine Reason is manifested, which has planted and maintains through them both the knowledge of the good and the movement toward it. As we could observe, virtues belong to the upper part of the soul, to the intellect, but they do not remain the virtues of the intellect (intellectual virtues as Aristotle called them) because they maintain and develop all this superior form of manifestation of the soul (contemplation, reason and will) in the body; the former equals the three theological virtues: faith, hope and love.

\section{BIBLIOGRAPHY:}

\section{Editions and translations from Romanian to English from Saint Maximus}

[1] Ambigua, PG. 1061-1417C, rom. translation by Pr. D. Stăniloae in Parents and Writers of the Church (PSB), vol. 80, EIBMBOR, Bucharest,1983

[2] Disputo cum Pyrrho, PG 91, 288-353; rom. translation by Father. D. Stăniloae in Scrieri II. Scrieri și epistole duhovnicești (Writings II. Writings and spiritula Letters), col. PSB, vol. 80, EIBMBOR, București 1990.

[3] Questiones ad Thalasium, PG 90, 244-785; rom. translation by Father Dumitru Stăniloae, in Filocalia românească (Romanian Philokalia), vol. III, Humanitas Publishing House, Bucharest, 2009

[4] Capita de charitate, PG 90, 959A-1080D; rom. translation in Philokalia, vol. II, translated by Prof. Ph.D. Dumitru Stăniloae, Humanitas Publishing House, Bucharest, 2009.

\section{Articles and other works:}

[5] BERDIAEV, Nicolai, Spirit and freedom. A test of Christian philosophy (Spirit și libertate. Încercare de filosofie creștină), translation by Stelian Lăcătuş, Paideia Publishing House, Bucharest, 2009.

[6] LOSSKY, Vladimir, God's vision (Vederea lui Dumnezeu), translated by Prof. Ph.D. Remus Rus, EIBMBOR, Bucharest, 1995.

[7] PAPANIKOLAOU, Aristotel, "Learning How to Love: Saint Maximus on Virtue", in: Knowing the Purpose of Creation Through the Resurrection-Proceeding of the Symposium on St. Maximus the Confessor, Sebastian Press \& The Faculty of Orthodox Theology, University of Belgrade, 2013.

[8] POPOVICH, Justin, St., The way of knowing God (Calea cunoașterii lui Dumnezeu), Romanian translation by. Monahia Domnica (Țalea), Egumenița Publishing House, Galați 2014.

[9] TATAKIS, Basile, Byzantine philosophy (Filosofia Bizantină), translation from French by Eduard Florin Tudor, Second Edition, Nemira, Bucharest, 2013.

${ }^{27}$ Idem, Ambigua, PG. 91, col. 1106C; rom. Transl., p. 104. 